\title{
Ethno-Therapeutic Remedies for JAUNDICE, in Dang Dt. Gujarat, India
}

\author{
Thresia Paul
}

St. Xavier's Himatnagar

\begin{abstract}
In this paper Ethno-Therapeutic Remedies for JAUNDICE, in Dang Dt. Gujarat, India, we have described 16 different therapies for jaundice from 17 traditional healers hailing from 17 villages and documented them with the medicinal plants' local name, botanical name, parts used, preparation and dosage 27 medicinal plants that are used for healing Jaundice are given in table 2 with their scientific name, family, habit, local names, and parts used. Jaundice is one of the common problems faced by the people of Dangs. Traditional healers of this region totally depend on plants for healing jaundice.95\% of Dang district is covered by forests. The forest contains wide variety of trees and herbs that have high medicinal values. Medicinal plants like Cassia tora, Dalbergia volubilis, Oroxylum indicum, Pterocarpus are refereed by more than one Traditional healer for curing Jaundice.
\end{abstract}

Keywords: Traditional healers, medicinal plants, Jaundice, Therapy, Ethno botany, traditional healers, Medicinal plants, Botanical Name, Local Name, Preparation, Dosage,

\section{Introduction}

Jaundice is a common ailment found in young and old, all over the world. Jaundice, also known as icterus, ${ }^{[1]}$ is a yellowish pigmentation of the skin, the conjunctival membranes over the sclera (whites of the eyes), and other mucous membranes, caused by high blood bilirubin levels. ${ }^{[2]}$ This hyperbilirubinemia causes increased levels of bilirubin in the extracellular fluid. Concentration of bilirubin in blood plasma is normally below $1.2 \mathrm{mg} / \underline{\mathrm{dL}}(<25 \underline{\mu \mathrm{mol}} / \mathrm{L})$. A concentration higher than approx. $3 \mathrm{mg} / \mathrm{dL}(>50 \mu \mathrm{mol} / \mathrm{L})$ leads to jaundice. ${ }^{[3]}$ The term jaundice comes from the French word jaune, meaning yellow. Fighting against jaundice is one of the main concerns of the world today. If proper treatment is not taken, the patients can lose their life. Even though people use modern medicine for treating jaundice, then also they depend on herbal therapy for wholesomeness after the effect of jaundice. The traditional healers of Dangs totally depend on herbal medicine for curing jaundice. They make decoction or extract after mixing parts of two or more medicinal plants. More than $90 \%$ of the population of Dangs depend on herbal medicine for curing jaundice. The moist deciduous forest of Dangs, in South Gujarat has an extraordinary diversity of plant species and has been regarded as treasure trove of medicinal plants.

DANG: The Study Area: a Location, Topography and Geomorphology

The study tract falls between the parallels of latitude 20.33 " 53 " and 21.4 '52" and the meridians of longitude 73.27' 58" and 73.56'36". The Dang forest tract starts from the rugged mountain chains of Sahyadri in the east and descends on the western side extending to the edge of plains of Gujarat. The District of Dangs has geographical area of 1778 Sq. Km. The entire population is rural living. The forest area which is about 95\% of the total geographical area and it comprises of 844.06 Sq. km Reserved Forest and 854.50 sq. km Protected Forest. Dangs contributed about $70 \%$ of the total major forest produce of Gujarat state, and about 15 lakhs bamboos produced that contribute about 50\% of the state production. In this area a vide variety of medicinal plants are found. People of this area depend on plants for curing most of their ailments. The traditional healers of this area have a deep knowledge of the medicinal values of the plants and have good collection of information about its uses. They won't let out easily this information to anyone.

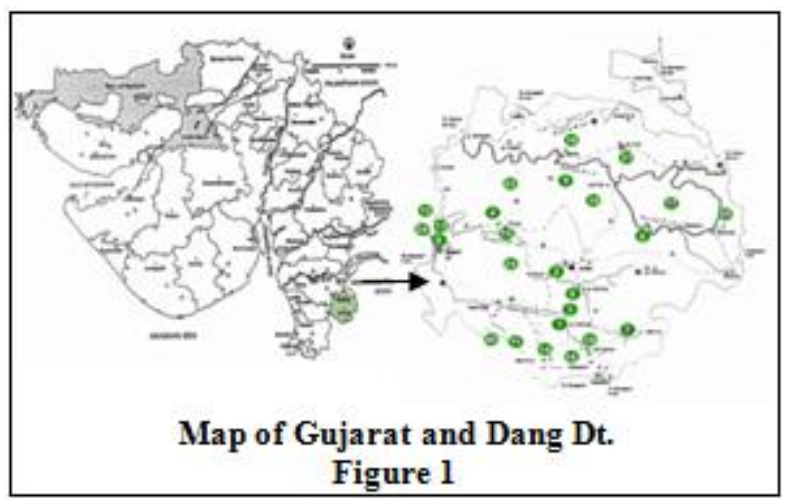

\section{Materials and Methods}

The research was conducted in several potential stands of the area during the year 2012 to 2014. For the data collection, 42 traditional healers, who are native to this area, were interviewed. A translator who knows both Guajarati, the state language and Dangi the local language, helped the researcher to document the information accurately. The researcher along with herbal healers visited the forests to identify the plants. Using the Botanical knowledge of the guide the plants were identified. Herbal healers of this area treat almost every disease with the help of herbal medicine. 


\section{International Journal of Science and Research (IJSR) \\ ISSN (Online): 2319-7064 \\ Index Copernicus Value (2013): 6.14 | Impact Factor (2014): 5.611}

Table 1: Details of the Traditional healers

\begin{tabular}{|c|c|c|c|}
\hline Sr. No & Names & $* \boldsymbol{n}$ & Villages \\
\hline 1 & Somabhai V.Moris & $* 1$ & Zari \\
\hline 2 & Shukarbahi & $* 2$ & Sathbabla \\
\hline 3 & Punyabhai J.Gavit & $* 3$ & Dhuda \\
\hline 4 & Sureshbahi R. Powar & $* 6$ & Gaygotton \\
\hline 5 & Maganbhai G.Gavit & $* 9$ & Pimpri \\
\hline 6 & Sukliyabhai Z. Marali & $* 10$ & Dungarada \\
\hline 7 & Jivalibahi J.Vad. & $* 11$ & Vati \\
\hline 8 & Ramubhai K. Raut & $* 13$ & Borigoutan \\
\hline 9 & Gamjibahi P.Bahtt & $* 14$ & Pimpri \\
\hline 10 & Janakbhai G.Kamadi. & $* 21$ & Bapkal \\
\hline 11 & Iktyabahi J.lya Powar & $* 23$ & Chirapada \\
\hline 12 & Mohanbhai B.Thakare & $* 28$ & Gundvahal \\
\hline 13 & Vasantbhai R. Powar & $* 29$ & Nalagchod \\
\hline 14 & Kasiya A. Deshmukh & $* 31$ & Soupdahad \\
\hline 15 & Abaji Julpia Valevi & $* 32$ & Bapkal \\
\hline 16 & Jayram S. Kuver. & $* 37$ & Gana \\
\hline 17 & Ashokbhai K. Galvi & $* 39$ & Subir \\
\hline \multicolumn{4}{|c}{$*$ The village numbers indicated in the map. } \\
\hline
\end{tabular}

It is very interesting to know how different traditional healers use different combination of medicinal plants for treating a particular ailment. In Ethno-Therapeutic Remedies for Jaundice out the 42 traditional healers the researcher studied, 17 of them gave information related to this paper. They were from different villages of Dangs. During the study trip the researcher carried field work based

\section{Results}

When one is with Jaundice the excess bilirubin causes the skin, eyes and mucus membranes in the mouth to turn a yellowish color. 16 different ways of treating for Jaundice is given here. Different information given by 17 traditional healers of different villages are documented and presented in Roman numbers. The source from where the information was obtained is indicated with $\left(*^{*} n\right) . n$ is the village number which is given in Figure1 and in Table 1. Each Traditional healer has uses a typical combination of medicinal plants in herbal therapy. Some of them use only one medicinal plant in their therapy, while some others use a combination of two or more medicinal plants for ethno therapy. The 16 medicinal plants that are used are listed with its their botanical name, family, local name, habit and parts that are used in Table 2.

\section{Ethno-Therapeutic Remedies for JAUNDICE are} given below.

\section{i. Nili choti, Dalbergia volubilis, Leaves $* 3, * 39$}

Preparation: The leaves of Nilichoti are crushed and the extract is taken.

Dosage: The extract is taken twice a day, morning on an empty stomach and in the evening after supper.

\section{ii. Guvita, Acacia polyacantha, Bark;}

Bivla, Pterocarpus marsupium, Bark*3

Preparation: These barks are crushed and soaked in water for $2 \mathrm{hrs}$, and the filter is collected.

Dosage: Half cup of it is taken twice a day, morning on an empty stomach and in the evening after supper. on observations, interviews and guided field trips, with the help of local personnel. The names of the traditional healers and their village names are given in table 1 . The numbers of villages are given in the figure 1.The work was carried out in the following objective sequence.

1) Extensive surveys were carried out during the field work; interviews were conducted with the Traditional Healers in the presence of a person who can translate the local language very efficiently. 42 traditional healers were interviewed from 25 different villages of Dangs. Out of the 42 traditional healers whom the researcher studied, 17 of them from different villages gave information pertaining to Jaundice. Through questioning and discussion, different combinations of plants that are used for various diseases, how to prepare the medicine and when and how much should be taken were documented.

2) In order to make sure the medicinal plants' botanical identity made visits to the forest for identification, and documented with their local names and botanical names.

3) After Analytical study on the information, therapeutic information was grouped under different titles and subtitles; prepared a synoptic view of medicinal plants with their botanical name, family, local name, habit and parts used. The paper Ethno-Therapeutic Remedies for Jaundice is part of the research thesis.

\section{iii. Chav, Ensete superbum, Sap from the cut loom*3}

Preparation: The loom of Chav is cut and its sap is collected a vessel.

Dosage: One teaspoonful of it is taken twice a day, morning and in the evening.

\section{iv. Chav, Ensete superbum, Sap from the cut loom;}

Pavuta, Costus speciosus, Cane*6

Preparation: The loom of Chav is cut and its sap is collected a vessel.

Dosage: One teaspoonful of it is taken twice a day, morning and in the evening. After each dose eat 3 inch long Pevuta stem.

\section{v. Sugar cane, Sacharum officinarum, Cane;}

Kumedio (Tuveria), Cassia tora, Tender leaves;

Dathura, Datura metel, Tender leaves*9

Preparation and application:

1. The sugar cane is cut into small pieces and kept in the open air at night so that the dew drops fall on it. The sugarcane pieces are chewed early in the morning on an empty stomach.

2. Tender leaves of Dhatura are crushed and made into a paste and are kept on the head for three days. Body bath is taken twice in a day.

3. Tender leaves of Tuveria are crushed and the extract is taken.

Dosage: Half cup of the extract is taken twice a day.

\author{
vi. Jangali Bhendi, Azanza lampas, Root; \\ Tetu, Oroxylum indicum, Bark; \\ Sag-Tectona grandis, Bark; \\ Haldava, Adina cordifolia, Bark; \\ Polas, Butea monosperma, Bark*10
}




\section{International Journal of Science and Research (IJSR) \\ ISSN (Online): 2319-7064 \\ Index Copernicus Value (2013): 6.14 | Impact Factor (2014): 5.611}

Preparation: All these mixtures are crushed and kept in water for few hours and then the extract is taken.

Dosage: Half cup of the extract is taken twice a day.

Application

Saslani guchadi, Asparagus racemosus, Root*10

Fleshy root is tied tightly on to the neck for about a week.

vii. Biya, Pterocarpus marsupium, Bark

Tetu, Oroxylum indicum, Bark

Tarut, Cassia tora, Root

Chokachik Sida sp., Root

Kardhaman, Grewia hirsute, Root*13

Preparation: All these plant parts are crushed and soaked in water and the extract is taken.

Dosage: Half a cup of the extract is taken twice in a day, in the morning and in the evening.

viii. Bivla, Pterocarpus marsupium, Bark;

Khumbi, Careya arborea, -Bark;

Inka, Caceria tomentosa, Leaves;

Bendvel-dhaman, Viscum articulatum on Grewia tiliifolia, Whloe plant*14

Preparation: All these plant parts are crushed, soaked and boiled with a bucket of water.

Dosage: Half a cup of the decoction is taken twice in a day, in the morning and in the evening. The rest of the water is used for bath after cooling it.

Bivla sticks are smoked.

Dosage: Take one tablespoonful twice a day; morning on an empty stomach and evening after the meals. Continue this therapy for a week.

\section{xiii. Kamal, Nymphaea nouchali, Rhizome *31}

Preparation: The above mentioned plant part is crushed and soaked in a glass of water, and the extract is taken after half an hour.

Dosage: Take one tablespoonful twice a day; morning on an empty stomach and evening after the meals. Continue this therapy for a week.

\section{xiv. Saslani guchadi , Asparagus racemosus, Root*11}

Preparation: The above mentioned plant part is crushed and soaked in a glass of water, and the extract is taken after half an hour.

Dosage: Take one tablespoonful twice a day; morning on an empty stomach and evening after the meals. Continue this therapy for a week. ix. Nilisoti, Dalbergia volubilis, Leaves;

Taruta, Cassia tora, Root*21

Preparation: Equal portions of these plant parts are crushed and the extract is taken.

Dosage: Half cup of the extract is taken twice a day, morning on an empty stomach, evening after the meals. This is continued up to a week.

x. Choki Bendi, Hibiscus esculentus, Root; *23*32

Preparation: The root of the above mentioned plant is crushed and soaked in water for an hour and the extract is taken.

Dosage: Half cup of the extract is taken thrice daily, morning before the meals, after noon and night after the meals.

\section{xi. Kosim Schleichera oleosa-Bark*28}

Preparation: The above mentioned plant part is crushed and soaked in a glass of water, and the extract is taken after half an hour.

Dosage: Take one tablespoonful twice a day; morning on an empty stomach and evening after the meals. Continue this therapy for a week.

\section{xii. Tettu, Oroxylum indicum, -Bark *29}

Preparation: The above mentioned plant part is crushed and soaked in a glass of water, and the extract is taken after half an hour.

xv.Safed Musali, Chlorophytum borivilianum, Fleshy root, Saslani guchadi, Asparagus racemosus, Root *37

Preparation: 2-3 fleshy roots are crushed and boiled with milk and drank.

3 hours later, two fleshy roots of shevur are crushed and soaked in a glass of water for about $10 \mathrm{~min}$. and the extract is taken and drunk.

Dosage: This procedure is done morning and evening for up to a week.

xvi. Sinti, Phoenix sylvestris, Soft stem

Neelgiri Eucalyptus tereticornis, Bark;

Babhali, Acacia nilotica, Root *1

Preparation: The above mentioned plant parts are crushed and soaked in a glass of water, and the extract is taken after half an hour.

Dosage: Take one tablespoonful twice a day; morning on an empty stomach and evening after the meals. Continue this therapy for a week. 


\section{International Journal of Science and Research (IJSR) \\ ISSN (Online): 2319-7064}

Index Copernicus Value (2013): 6.14 | Impact Factor (2014): 5.611

Table 2: A synoptic View of medicinal plants used for Jaundice

\begin{tabular}{|c|c|c|c|c|c|}
\hline Sr. No & Botanical Name & Family & Local name & Habit & Parts Used \\
\hline 1 & Acacia nilotica & Mimosaceae & Bavad, Babali & Tree & Root \\
\hline 2 & Acacia polycantha & Mimosaceae & Gubita & Tree & Bark \\
\hline 3 & Adina cordifolia & Rubiaceae & Haldava & Tree & Bark \\
\hline 4 & Asparagus racemosus & Liliaceae & Sevara,Sevur, Saslana lindi, Saslana gugadi & Climber & Root \\
\hline 5 & Azanza lampas & Malvaceae & Ran Bhendi,Jangali Bhendi & Shrub & Root \\
\hline 6 & Butea monosperma & Fabaceae & Polas, Kaharo & Tree & Bark \\
\hline 7 & Careya arborea & Barringtoniaceae & Kumbi, Kumbhiya & Tree & Bark \\
\hline 8 & Caseria tomentosa & Flacourtiaceae & Ilangi, ingi & Tree & leaves \\
\hline 9 & Cassia tora & Caesalpiniaceae & Thevara, Taruta & Herb & Leaves, root \\
\hline 10 & Chlorophytum borivilianum & Liliaceae & Musali, Kauni bahji & Herb & root \\
\hline 11 & Costus speciosus & Zingiberaceae & Pevuta & Herb & cane \\
\hline 12 & Dalbergia volubilis & Fabaceae & Nili choti & Shrub & Leaves \\
\hline 13 & Datura metel & Solanaceae & Dathura & Shrub & leaves \\
\hline 14 & Ensete superbum & Musaceae & Chav Jangali kel & Herb & Sap \\
\hline 15 & Eucalyptus tereticornis & Myrtaceae & Neelgiri & Tree & Bark \\
\hline 16 & Grewia hirsute & Tiliaceae & Kardhaman & Tree & Root \\
\hline 17 & Grewia tiliifolia & Tiliaceae & dhaman & Tree & bark \\
\hline 18 & Hibiscus esculentus & Malvaceae & Choki, Bendi & Shrub & Root \\
\hline 19 & Nymphaea nouchali & Nymphaeaceae & Kamal & Herb & Rhizome \\
\hline 20 & Oroxylum indicum & Bignoniaceae & Tettu & Tree & Bark \\
\hline 21 & Phoenix sylvestris & Arecaceae & Sinti & Tree & Soft stem \\
\hline 22 & Pterocarpus marsupium & Fabaceae & Bivla & Tree & Bark \\
\hline 23 & Sacharum officinarum & Poaceae & Sugar cane & Grass & Cane \\
\hline 24 & Schleichera oleosa & Sapindaceae & Kosim & Tree & Bark \\
\hline 25 & Sida $s p$ & Malvaceae & Chokachik & Shrub & Root \\
\hline 26 & Tectona grandis & Verbenaceae & Sag & Tree & Bark \\
\hline 27 & Viscum articulatum & Violaceae & Bendvel & Parasite & Whole plant \\
\hline
\end{tabular}

\section{Discussion}

$95 \%$ of the Dang Dt. is completely covered by forest. Due to the hilly nature of the terrain, and most of the people living in forests away from cities or village health centres, they are forced to depend on nature to cure almost all their ailments. The names of the traditional healers and their village names are given in the Table1. $\left({ }^{*} n\right)$ is the village number indicated in the map. In this paper Ethno-Therapeutic Remedies for JAUNDICE, 16 different modes of therapy by 17 traditional healers hailing from 17 villages are documented and presented. In order to identify the source of information the village of the traditional healer is indicated with $\left({ }^{*} n\right)$ which is the village number shown in the Table1. Also the villages are numbered in Dang Map in Figure1.

Each Traditional healer uses a typical combination of medicinal plants in their herbal therapy Ethno-Therapeutic Remedies for JAUNDICE. Some of them cure Jaundice with only one medicinal plant, while others use a combination of two or more medicinal plants in their ethno therapy.

Many of the herbal healers use any one of these medicinal plants from Hibiscus esculentus, Ensete superbum, Dalbergia volubilis or Asparagus racemosus for healing Jaundice.

Two Herbal healers heal Jaundice with Dalbergia volubilis alone .Two of the herbal healers heal Jaundice only with Hibiscus esculentus, whereas three other herbal healers use Ensete superbum alone or in combination with Costus specious for healing Jaundice.
Medicinal plants like Cassia tora, Dalbergia volubilis, Oroxylum indicum, Pterocarpus marsupium, Ensete superbum are used by more than three herbal healers with a typical combination to prepare herbal medicine for Jaundice. Each of the medicinal plants Ensete superbum, Asparagus racemosus, Hibiscus esculentus are used by two herbal healers in the preparation of herbal medicine.

The medicinal plant Oroxylum indicumis is used by three traditional healers for curing Jaundice. All three of them have different combination

Dalbergia volubilis + Cassia tora,

Oroxylum indicum + Cassia tora,

Oroxylum indicum + Asparagus racemosus,

Pterocarpus marsupium + Oroxylum indicum + Cassia tora. Pterocarpus marsupium is another medicinal plant used by three traditional healers for healing jaundice. Pterocarpus marsupium + Oroxylum indicum + Cassia tora another combination. All these medicinal plants are repeatedly used for curing Jaundice.

The 27 medicinal plants that are used are listed with their botanical name, family, local name, habit and parts that are used in Table 2. From the above study we have to give priority to the below given points.

1)It is important to find out the active compound from these medicinal plants that help to bring down the level of bilirubin in blood

2)It is also important to screen for active principles from these medicinal plants and do a comparative study with the existing medicines.

3)It is obvious that most of these medicinal plants are trees. Their roots or stem are utilized for medicinal purposes. there is a felt need to preserve these trees. For example

\section{Volume 5 Issue 3, March 2016}




\section{International Journal of Science and Research (IJSR) \\ ISSN (Online): 2319-7064 \\ Index Copernicus Value (2013): 6.14 | Impact Factor (2014): 5.611}

Pterocarpus marsupium's bark and gum are used for various ailments. Excessive destruction and not planting new may lead to extinction of these plants.

\section{Summary and Conclusion}

In this paper Ethno-Therapeutic Remedies for JAUNDICE, in Dang Dt. Gujarat, India, we have described 16 different therapies for jaundice from 17 traditional healers hailing from 17 villages and documented them with the medicinal plants' local name, botanical name, parts used, preparation and dosage. 27 medicinal plants that are used for healing Jaundice are given in table 2 with their scientific name, family, habit, local names, and parts used. Jaundice is one of the common problems faced by the people of Dangs. Traditional healers of this region totally depend on plants for healing jaundice.95\% of Dang district is covered by forests. The forest contains wide variety of trees and herbs that have high medicinal values. Medicinal plants like Cassia tora, Dalbergia volubilis, Oroxylum indicum, Pterocarpus marsupium are refereed by more than one Traditional healer for curing Jaundice.

It is important to screen for active principles from these medicinal plants and do a comparative study with the existing medicines

Further studies should be conducted to find out the active compound from these medicinal plants that help to bring down the level of bilirubin in blood. It is also important to protect the medicinal plants that are endangered.

\section{Acknowledgement}

The author is thankful to all the Herbal healers, translators and all those helped me. I would like to express sincere gratitude to the Jesuit fathers and Vedruna sisters who are working at Subir, Pimpri and Shamghahan in Dang Dt. for providing accommodation and introducing the Traditional healers and guides to visit the villages. Sincere thanks to the guide, proof reader and all those have helped to publish this paper.

\section{References}

[1] "Definition of Icterus". MedicineNet.com. 2011. Retrieved 3 February2013.

[2] Click, Rachel; Dahl-Smith, Julie; Fowler, Lindsay; DuBose, Jacqueline; Deneau-Saxton, Margi; Herbert, Jennifer (2013). "An osteopathic approach to reduction of readmissions for neonatal jaundice". Osteopathic Family Physician 5(1): 17-23. doi:10.1016/j.osfp.2012.09.005.

[3] Silbernagl S, Despopoulos A (2009). Color atlas of physiology (6th ed.). Thieme. p. 252. ISBN 978-3-13545006-3.

[4] Arora R.K., Ethnobotany and its role in the conservation and use of plant genetic resources in India, Ethnobotany, 9,6-15 (1997)

[5] Bhogaonkar P.Y. and Deokule S., Some useful ethnomedicinal plants of Korku of Melghat region (MS), Ethnobotany, 12(1-2), 16-19 (2002)
[6] Dixit, A.M. \& Subba Rao, S.V. (2000). Observation on distribution and habitat characteristics of Gugal (Commiphora wightii) in the arid region of Kachchh, Gujarat (India). Tropical Ecology. 41 (1): 81-88.

[7] Eilu, G. \& Bukenya-Ziraba, R.. (2004). Local use of climbing plants of Budongo forest reserve, Western Uganda. Journal of Ethnobiology. 24 (2): 307-327.

[8] Gadgil, M., Rao P.R.S., Utkarsh, G. \& Chhate, A. (2000). New meaning for old knowledge: The people's biodiversity registers programme. Ecological Applications. 10: 1307-1317.

[9] Ibrar M., Responsibilities of ethnobotanists in the field of medicinal plants, In Proceeding of Workshop on Curriculum Development in Applied Ethnobotany. Ethnobotany Project, WWF Pakistan, 34-D/2:16-20 (2002)

[10] Nadkarni K.M., Indian plants and drugs with their medicinal properties and uses. Asiatic publishing House, New Delhi (2001)

[11] Pranjali J.D. and Pei S.J., Ethnobotanical approaches of traditional medicine studies some experiences from Asia, 39, 74-79 (2001)

[12] http://www.censusindiamaps.net/page/India_WhizMap /IndiaMap.htm "District Census 2011". Census2011.co.in. 2011. Retrieved 2011-09-30.

[13] Reddy A .S. Flora of Dharampur forest, PhD Thesis, (Sardar Patel University, Vallabh Vidyanagar, Gujarat), 1986

[14] Nirmal Kumar JI, Hiren Soni \& Rita N Kumar, Ethnobotanical values of certain plant species of Dang forest, extreme northern parts of Western Ghats, South Gujarat, India, J Curr Biosci,2 (1) (2004) 63-74.

[15] Nirmal Kumar at el., Studies on plant species used by tribal communities of Saputara and Purna forests, Dangs district, Gujarat, India., Journal of Traditional Knowledge; Vol. 6(2), April 2007, pp. 368-374

[16] Thresia at al., Therapeutic and Ethnobotanical Investigations in Dangs Dt. Gujarat state. India. World Journal of Science 2013; 1(2): 118-132

[17] Thresia Paul \& MM Prajapati, Ethno-Therapeutic Remedies for Bone Fracture, Dang Dt. Gujarat. India, IOSR Journal of Pharmacy and Biological Sciences, Volume 9, Issue 2 Ver. II (Mar-Apr. 2014), PP 45-50

[18] Thresia Paul, Ethno-Therapeutic Remedies for women's problems, Dang Dt. Gujarat. India, International Journal of Science and Research (IJSR), Volume 5 Issue 3, March 2016, pp 822-828 